\title{
Use of alternative and complementary therapies in labor and delivery care: a cross-sectional study of midwives' training in Catalan hospitals accredited as centers for normal birth
}

\author{
Ester Muñoz-Sellés ${ }^{1}$, Antoni Vallès-Segalés ${ }^{2}$ and Josefina Goberna-Tricas ${ }^{1 *}$
}

\begin{abstract}
Background: The use of complementary and alternative medicine (CAM) and complementary and alternative therapies (CAT) during pregnancy is increasing. Scientific evidence for CAM and CAT in the field of obstetrics mainly covers pain relief in labor. Midwives are responsible for labor and delivery care: hence, their knowledge of CAM and CAT is important. The aims of this study are to describe the professional profile of midwives who provide care for natural childbirth in Catalan hospitals accredited as centers for normal birth, to assess midwives' level of training in CAT and their use of these therapies, and to identify specific resources for CAT in labor wards.
\end{abstract}

Methods: A descriptive, cross-sectional, quantitative method was used to assess the level of training and use of CAT by midwives working at 28 hospitals in Catalonia, Spain, accredited as public normal birth centers.

Results: Just under a third of midwives (30.4\%) trained in CAT after completion of basic training. They trained in an average of 5.97 therapies (SD 3.56). The number of CAT in which the midwives were trained correlated negatively with age $(r=-0.284 ; p<0.001)$ and with their time working at the hospital in years $(r=-0.136 ; p=0.036)$. Midwives trained in CAT considered that the following therapies were useful or very useful for pain relief during labor and delivery: relaxation techniques (64.3\%), hydrotherapy (84.8\%) and the application of compresses to the perineum (75.9\%). The availability of resources for providing CAT during normal birth care varied widely from center to center.

Conclusions: Age may influence attitudes towards training. It is important to increase the number of midwives trained in CAM for pain relief during childbirth, in order to promote the use of CAT and ensure efficiency and safety. CAT resources at accredited hospitals providing normal childbirth care should also be standardized.

Keywords: Midwife, Complementary and alternative medicine (CAM), Training

\section{Background}

Complementary and alternative medicine (CAM) comprises a very wide group of therapeutic practices that are not habitually used by conventional or allopathic health professionals [1-6].

The percentages of the population who report having used CAM at least once vary considerably, from $80 \%$ in Africa, $70 \%$ in Canada, $49 \%$ in France, $46 \%$ in Australia, $42 \%$ in the US, $40 \%$ in China, $31 \%$ in Belgium and $18 \%$

\footnotetext{
* Correspondence: jgoberna@ub.edu

${ }^{1}$ Department of Public Health, Mental Health and Perinatal Nursing, University School of Nursing, University of Barcelona, Barcelona, Spain Full list of author information is available at the end of the article
}

in Holland $[7,8]$. According to a study by the Spanish Ministry of Health's Observatory of Natural Therapies, $95 \%$ of the Spanish population are aware of natural therapies and 23\% have used one [8]. The US National Center for Complementary and Alternative Medicine (NCCAM) defines a complementary therapy as one that is used together with conventional medicine, whereas an alternative therapy is one used in the place of conventional medicine [9].

The term "integrative medicine" is used to refer to the combination of conventional and alternative medicine practices that meets the requirements of scientific evidence, safety and effectiveness [9-12]. Though regulations 
and funding vary from country to country, healthcare professionals are increasingly likely to prescribe alternative and complementary therapies (CAT) [13-15]. At the National Conference on Nursing and Medical Education, it was recommended that training for healthcare professionals should include CAM [16]. There is no consensus on current educational programs in different countries, but there is clearly a need to relate CAM training with evidence-based medicine [17-23]. In Spain, as CAM training for healthcare professionals is not regulated, their familiarity with the area varies widely [8]. CAM and CAT are offered as optional subjects at certain nursing schools, but not in a systematic way [24]; as a result, students do not gain a thorough grounding in the use of these therapies [11]. On qualifying, nurses who are interested in furthering their knowledge of CAM must seek postgraduate training available at certain universities or professional institutions [5-25]. In Spain, midwife training is a specialty of nursing [5]. In 2002, the International Confederation of Midwives published guidelines for basic midwifery knowledge, skills and behaviors that are essential to risk-free practice. Competency No. 4 includes comfort measures in labor, such as emotional support and non-pharmacological methods of pain relief [26]. In Spain, the current training program for midwives comprises two years of full time study, with a total of 3534 hours. Two thirds of the program is devoted to practical training in hospitals and outpatient centers. The theoretical training includes aspects such as the use of non-pharmacological techniques for pain relief during birth, including relaxation and breathing techniques, emotional support, techniques to promote mobility during labor, and the application of cold compresses to the perineum [5-26]. The amount of practical training in CAT given depends on the extent to which these treatments are used at the hospital where the student is training. Postgraduate training for midwives is usually shared with nurses and other health professionals. There are few specific training resources in CAM and CAT for trainee midwives.

Pettigrew (2002) stated that almost 70\% of expectant mothers use some kind of CAM at the end of pregnancy, and that some of the practices tend to be self-prescribed [27]. Other studies suggest that the use of traditional medicine and CAT is not significantly associated with adverse obstetric events. [28] Scientific evidence for CAT in the field of obstetrics mainly covers pain relief in labor by relaxation and yoga [29] acupuncture, acupressure and hypnosis [30-32] warm water immersion during labor [33,34] and continuous support [35] as well as perineal pain relief through the application of cold compresses to the perineum [36]. There are contradictory recommendations on the use of the transcutaneous electrical nerve stimulation (TENS) technique - which is already applied in other clinical processes - for pain relief in the first stage of labor [32-37] and there is no consensus on the use of sterile water injections in the lumbar region [32-38]. More scientific evidence is required in these two areas. All these techniques are suitable for low-risk pregnancies and deliveries [25]. During the twentieth century, childbirth care in Spain became increasingly medicalized. However, pressure from women's groups, associations and institutions led the health authorities to promote approaches to labor and delivery care that involve less intervention [34]. Various healthcare protocols and strategies have emerged to support normal, non-medicalized birth; improving the quality of professional care, taking a woman-centered approach, giving up harmful, unnecessary practices and maintaining current levels of safety [39-44]. The participation of the midwife in normal delivery care is central to all these strategies, and most of them include birth plan templates with various proposals for alternative pain relief methods (CAT). The idea is that expectant mothers should be able to choose from a range of tools that ease discomfort and pain during delivery $[39,45,46]$ and so midwives must be familiar with CAT [47]. At the same time, health authorities have designed various strategic plans to improve the model of healthcare and to ensure that it reflects the philosophy of reducing the level of intervention. In 2007, the Spanish Ministry of Health and Consumer Affairs published a document entitled Estrategia de atención al parto normal en el Sistema Nacional de Salud (Strategy for Care in Normal Birth in the National Health System). The Spanish state is divided politically into Autonomous Communities, which have legislative and executive powers in the area of health. In Catalonia, which is one of these 17 autonomous regions, the regional Ministry of Health (the government body responsible for ensuring universal healthcare in Catalonia) has developed a policy of accrediting hospitals that are considered ready to provide care which respects the physiology of normal birth. The Ministry of Health provides subsidies for these hospitals to adapt their facilities, promote a training plan for professionals and acquire specific equipment. Recognized institutions are called "hospitals accredited for normal birth" and all of them belong to the public health system. In these hospitals, midwives are responsible for labor and delivery care. Hence, it is also in these hospitals that the importance of midwives' knowledge and training in CAT or alternative methods of pain relief during birth is evident [8-48]. Therefore, the aim of this study was to establish the level of CAT training of midwives at hospitals accredited as centers for normal birth, and to determine the infrastructure and resources available in these hospitals to offer CAT to women during birth.

Our objectives were to describe the professional profile of midwives who work in delivery rooms in Catalan 
hospitals that are accredited as centers for normal birth; to determine the level of training and use of CAT by these midwives; and to identify specific resources in the labor wards of accredited Catalan hospitals.

\section{Methods \\ Study design}

The study was descriptive and cross-sectional, and a quantitative method was used.

\section{Study area}

The study was conducted in Catalonia, where there are some 70 hospitals in total. We centered on the 28 public hospitals which, by 2011, had been accredited by the regional Ministry of Health as hospitals for normal birth.

\section{Subjects}

The study population comprised the 455 midwives who work at these hospitals.

Midwives were included in the study if they had worked for at least six months at one of the hospitals. This was considered the minimum amount of time required to ensure that midwives had experience in applying the normal birth care protocol. Midwives who did not wish to take part in the study and midwives in training were excluded.

\section{Measuring instruments}

A questionnaire drawn up by the research team was used to gather information from the midwives. It was based on two questionnaires compiled by Sara and Hastings-Tolsma $(2009)[49,50]$. The new questionnaire was adapted to the social, cultural and healthcare context and to the objectives of this study. The number of therapies under study was increased. Therapies were selected taking into account the results of studies in the literature on the CAT most frequently used during childbirth. In addition, questions on midwives' knowledge and training in CAT were adapted to the Spanish educational system.

\section{Description of the questionnaire}

The questionnaire can be found in Additional file 1. In the first section, the midwives provided personal and professional information. The aim of the second section is to examine midwives' training in CAT. In this section, midwives wrote down the number of hours of training they had received on each one of the proposed therapies, and stated when the training had taken place and the number of years' experience they had in its use. The third section was designed to find out midwives' perceptions of the degree of usefulness of CAT during labor and delivery, using a 5-point Likert scale. A specific table was drawn up for data on the material resources at the hospitals accredited as centers for normal birth. These data were supplemented by information from nursing supervisors on the labor wards (see Table 1). A pilot test of the questionnaire was carried out in November 2011 in order to revise contents and wording, and to estimate the completion time. The test was administered to ten midwives from one of the hospitals in the study, who completed the questionnaire twice in a fifteen-day period. Parts of the questionnaire that were difficult to understand were modified. The correlation between the two phases of questionnaire administration was measured using bivariate analysis. In the analysis of quantitative variables (Spearman's rank correlation coefficient) and the analysis of qualitative variables (Pearson's $x^{2}$ test), the correlations between the two questionnaires were higher than $88 \%$.

\section{Statistical analysis}

We conducted a descriptive analysis of the midwives' sociodemographic and professional variables, variables related to the hospitals in the study, and variables referring to CAT training. Descriptive statistics were summarized using the frequencies (percentages) for categorical variables. Means, standard deviations, medians, minimums and maximums were reported for all continuous variables. To compare variables, we used $X^{2}$ for categorical variables, the student's t-test for independent groups for categorical variables with two categories that met the applicability criteria, assuming equal variance, and the Pearson's correlation for two quantitative variables. A value of $\mathrm{p}<0.05$ was considered to be significant. The software used for the analysis was SPSS Statistics v20.

\section{Ethical aspects}

This study was approved by the University of Barcelona Bioethics Committee and the Ethics and Clinical Research Committee of the first two hospitals where data were compiled. The other hospitals authorized the study after examining the project and after being notified of the authorization granted by the Bioethics Committees of the University and the two first hospitals. An information session was held in each of the participating hospitals to explain the study aims and to request collaboration. At the end of the talk, a copy of the questionnaire was given to each midwife, along with an informed consent form. The nursing supervisor at each of the hospitals was in charge of keeping the questionnaires until the research team collected them two weeks later.

\section{Results}

Of the 465 questionnaires administered at the start of the study, 237 were returned fully completed. The overall response rate was $54.06 \%$. The response rate for different hospitals varied between 100\% and 13.33\%.

All of the nursing supervisors were women, with an average age of 46.82 years (SD 7.9). Of the midwives, $3.4 \%$ were male and $96.6 \%$ were female and the average 
Table 1 Midwives training in complementary and alternative therapies, 237 midwives

\begin{tabular}{|c|c|c|c|}
\hline & $\mathrm{N}(\%)$ & $\begin{array}{c}\text { Training hours } \\
\text { Average/SD }\end{array}$ & $\begin{array}{c}\text { Years of experience } \\
\text { Average/SD }\end{array}$ \\
\hline Deep-breathing exercises training & $180(75.9)$ & $30.76 / 53.72$ & $10.11 / 9.23$ \\
\hline Relaxation techniques training & $176(73.8)$ & $33.29 / 53.88$ & $10.59 / 8.99$ \\
\hline Continuous support training & $132(55.7)$ & $58.32 / 85.82$ & $9.97 / 9.04$ \\
\hline Postural therapy training & $127(53.6)$ & $27.56 / 44.53$ & $7.77 / 6.69$ \\
\hline Application perineum compresses training & $123(51.9)$ & $9.38 / 24.69$ & $5.4 / 4.7$ \\
\hline Massage training & $108(45.6)$ & $35.59 / 65.86$ & $7.71 / 6.71$ \\
\hline Guided imagery training & $101(42.6)$ & $21.02 / 26.81$ & $8.79 / 8.07$ \\
\hline Hydrotherapy training & $88(37.1)$ & $23.24 / 36.34$ & $5.18 / 5.27$ \\
\hline Homeopathy training & $72(30.4)$ & $16.25 / 16.94$ & $2.83 / 1.51$ \\
\hline Training in sterile water injections administration & $66(27.8)$ & $5.18 / 5.5$ & $3 / 2.23$ \\
\hline Music therapy training & $65(27.4)$ & $15.83 / 21.9$ & $7.38 / 6.81$ \\
\hline Reflex therapy training & $60(25.3)$ & $43.74 / 61.91$ & $5.47 / 5.67$ \\
\hline Yoga training & $41(17.3)$ & $88.86 / 158.18$ & $5,57 / 6.23$ \\
\hline Herbal medicine training & $41(17.3)$ & $44.68 / 76.68$ & $4.91 / 5.62$ \\
\hline Therapeutic touch training & $40(16.9)$ & $25.38 / 22.37$ & $6.31 / 7.13$ \\
\hline Transcutaneous electrical nerve stimulation (TENS) & $38(16)$ & $5.81 / 7.21$ & $3.9 / 2.35$ \\
\hline Aromatherapy training & $32(13.5)$ & $15.4 / 15.23$ & $4.78 / 4.48$ \\
\hline Flower essences training flower essences & $29(12.2)$ & $31.44 / 24.65$ & $4.49 / 3.9$ \\
\hline Acupressure training & $23(9.7)$ & $57.8 / 85.61$ & $3.9 / 2.4$ \\
\hline Acupuncture training & $19(8)$ & $110 / 134.4$ & $5.12 / 8.14$ \\
\hline Hypnosis training & $18(7.6)$ & $18.77 / 22.96$ & $5.3 / 6.73$ \\
\hline Reiki training & $13(5.5)$ & $41 / 74.84$ & $8,25 / 6.18$ \\
\hline Ear puncture training & $8(3.4)$ & $91.43 / 112.46$ & $8 / 11.4$ \\
\hline Orthomolecular medicine training & $4(1.7)$ & $33.5 / 25.6$ & $2.75 / 2.36$ \\
\hline
\end{tabular}

Midwives are trained in different therapies. The best training therapy is breathing technics $75.9 \%$ and the worse is orthomolecular medicine $1.7 \%$. In bold the 3 therapies more training in italics the 3 worse.

age was 41.21 years (SD 10.28). A total of $75.1 \%(\mathrm{n}=178)$ worked full-time and $18.4 \%(n=43)$ part-time. A total of 76.4\% $(n=181)$ had trained in Catalonia, 3.8\% $(n=9)$ in the rest of Spain, 9.3\% $(n=22)$ in South America and 9.3\% $(\mathrm{n}=22)$ in the rest of Europe. On average, midwives had worked for 14.64 years in the specialty (SD 12.3); 9.4 years in delivery care at their hospital (SD 8.9); and 6.2 years in care for normal childbirth (SD 7.38). Of the midwives surveyed, $89.87 \%(n=213)$ stated that they had trained in some form of CAT. On average, they had trained in 7.58 of the therapies under study (SD 4.21; minimum 1, maximum 23). If we exclude therapies that already form part of basic midwifery training, the percentage of midwives who trained in CAT after completion of basic training was $30.4 \%(n=72)$, in 5.97 therapies on average (SD 3.56; minimum 1 , maximum 18 ). Midwives were mainly trained in breathing techniques $75.9 \%(\mathrm{n}=180)$, relaxation techniques $73.8 \%(\mathrm{n}=176)$, continuous support $55.7 \%$ $(\mathrm{n}=132)$, postural therapy $53.6 \%(\mathrm{n}=127)$ and the application of compresses to the perineum 51.9\% $(\mathrm{n}=123)$. Very few midwives were trained in ear acupuncture $3.4 \%$ $(\mathrm{n}=8)$ and orthomolecular medicine $1.7 \%(\mathrm{n}=4)$ (see Table 2). Midwives trained in CAT considered that the following therapies were quite or very useful for pain relief during labor and delivery: relaxation techniques, hydrotherapy and the application of compresses to the perineum. However, they considered that the following CAT were hardly or not at all useful: acupuncture needles, sterile water injections in the lumbar region, hypnosis and TENS (see Table 2). A total of $39.3 \%$ of the midwives worked in a level I hospital (low technical complexity), $28.6 \%$ in a level II hospital (average technical complexity) and $32.1 \%$ in a level III hospital (high technical complexity). In Catalonia, there were 79,820 deliveries in 2011, of which 44,481 took place at the hospitals under study. The average number of births per hospital was 1594.04 (SD 934.9). A total of 6,075 women requested care for natural childbirth, but only 4,752 of them received such care. The percentages of natural births ranged from 71.51 to $5.66 \%$ at the Catalan hospitals under study. The hospital resources for providing care during normal births using CAT varied widely (see Table 3 ). We studied midwives' 
Table 2 Perceived usefulness of Scientific evidence recommended therapies

\begin{tabular}{|c|c|c|c|c|c|}
\hline For pain relief in labour & & Nothing or any & Regular & Rather or much & Total: \\
\hline Acupuncture needles applications & N (\%) & 10(55.5) & $5(27.7)$ & $8(44.4)$ & $18(100)$ \\
\hline Perineum compresses & & $3(3.6)$ & $17(20.5)$ & $63(75.9)$ & $83(100)$ \\
\hline Hydrotherapy & & $7(8.8)$ & $5(6.3)$ & $67(84.8)$ & $79(100)$ \\
\hline Hypnosis & & $2(20)$ & $3(30)$ & $5(50)$ & $10(100)$ \\
\hline Water injections & & $8(34.7)$ & $5(21.7)$ & $10(43.4)$ & $23(100)$ \\
\hline Massage & & $4(4.8)$ & $18(21.4)$ & $62(73.8)$ & $84(100)$ \\
\hline Relaxation techniques & & $7(5)$ & $43(30.7)$ & $90(64.2)$ & $140(100)$ \\
\hline Deep-breathing exercises training & & $6(3.8)$ & $44(28)$ & $107(68.1)$ & $157(100)$ \\
\hline Postural therapy & & $2(1.8)$ & $18(15.9)$ & $92(82.1)$ & $112(100)$ \\
\hline$\overline{\text { Transcutaneous electrical nerve stimulation }}$ & & $8(38)$ & $4(19)$ & $9(42.8)$ & $21(100)$ \\
\hline
\end{tabular}

perceptions of the usefulness of CAT for pain relief during labor and birth. No statistically significant differences were found for gender, specialty training school, length of time that the hospital had been accredited as a normal birth center, type of work contract, length of time since training in the specialty, level of care provided by the hospital and years of experience in providing care for normal delivery versus the number of CAT in which the midwives had trained, as well as the hours and total years of training in the CAT under study. The total number of CAT in which the midwives were trained correlated negatively with age $(\mathrm{r}=-0.284 ; \mathrm{p}<0.001)$ and with the years in which midwives had been working at the hospital $(r=-0.136$; $\mathrm{p}=0.036)$.

\section{Discussion}

The response rate in this study was $54.06 \%$, which is similar to that found in other studies [51]. One explanation for the high non-response rate is that midwives with no CAT training did not complete the questionnaire. This, together with the fact that the questionnaire was only administered in hospitals accredited as centers for normal birth, could explain why midwives in this study had a high percentage $(89.87 \%)$ of CAT training. This result corroborates the findings of Bjerså (2012), who observed that $80 \%$ of nurses had CAT training [52]. The percentage of training is lower in other studies. Forcades (2004) reported that 54\% of cases medical students consider that they have sufficient knowledge of alternative

Table $\mathbf{3}$ Hospital resources of the $\mathbf{2 8}$ hospitals studied in reference to natural birth

\begin{tabular}{|c|c|c|c|c|}
\hline Classification & Therapies & & $\begin{array}{l}\text { Resource owned } \\
\text { hospitals. N (\%) }\end{array}$ & $\begin{array}{l}\text { Number of hospitals that } \\
\text { allow women bring home } \\
\text { her remedy. } \mathrm{N}(\%)\end{array}$ \\
\hline \multirow[t]{2}{*}{ Biological techniques } & & Phytotherapy & $4(14.3)$ & $2(7.14)$ \\
\hline & & Orthomolecular medicine & 0 & \\
\hline \multirow[t]{7}{*}{ Mind-body medicine } & Hydrotherapy & Bath & $12(42.9)$ & \\
\hline & & Hot water bottles & $21(75)$ & \\
\hline & & Shower & $27(96.4)$ & \\
\hline & Music therapy & Radio-cd & $22(78.6)$ & $2(7.14)$ \\
\hline & & Perineum compresses & $24(85.7)$ & \\
\hline & Postural therapy & Birth bed & $27(96.4)$ & \\
\hline & & Balls & $28(100)$ & \\
\hline \multirow[t]{2}{*}{ Whole medical systems } & & Homeopathy & $3(10.7)$ & $5(17.85)$ \\
\hline & & Acupuncture needles & 0 & \\
\hline \multirow{4}{*}{$\begin{array}{l}\text { Manipulative and } \\
\text { body-based practices }\end{array}$} & & Water injections & $12(42.9)$ & \\
\hline & Massage aromatherapy reflex therapy & Massage oils & $8(28.6)$ & $3(10.7)$ \\
\hline & & Essentials oils & $4(14.3)$ & $3(10.7)$ \\
\hline & Transcutaneous electrical nerve stimulation & TENS & $9(32.1)$ & \\
\hline Energetic therapies & & Bach remedies & $1(3.6)$ & $4(14.28)$ \\
\hline
\end{tabular}


medicines [53]. Shorofi (2010) stated that $40 \%$ of nurses were not trained in CAT [54]. In Catalonia, the Nurses' Association of Barcelona considers that $25.5 \%$ of nurses use alternative therapies [11] and Fernandez (2010) found $58.8 \%$ of nurses who care for cancer patients have CAT training [55]. The basic midwifery training program in Spain includes relaxation and breathing techniques, position changes and continuous support for women during labor and birth. These techniques are recommended for all women, whether they want a more natural or more medicalized birth. When we excluded these techniques from the total number of alternative therapies in which midwives in this study were trained, we found that only $30.4 \%$ (72) had training in other more specific CAT. These data are similar to those found in a study carried out in Germany by Wiebelitz (2009) [56]. Midwives' opinions about the use of CAT differed: Some considered that more solid evidence was required to recommend them, whilst others believed that they were useful and safe during pregnancy [27-57]. Midwives' perceptions of the utility of CAT may be due to the fact that they were unaware of the institutional recommendations on pain relief techniques and had little experience in their application. The results show a negative correlation with age and midwives' years of work at the hospital: midwives who were older and had more years of experience tended to have less CAT training [58]. Indeed, age may influence attitudes towards training [59].

\section{Conclusions}

It is important to reach a consensus on the definitions of normal birth, so that we can compare data from different hospitals. The results of this study indicate that some midwives are trained in CAT but cannot apply the therapies, due to a lack of specific equipment or insufficient resources in their hospitals. Consequently, more resources should be made available for the use of CAT in normal birth care, in terms of training, infrastructure and equipment. CAT should be included in the care protocols for labor wards, so that professionals can use them in their daily work. In 1995, the WHO stressed the importance of qualifications for CAT professionals and providers, and the need to incorporate CAT in the training of healthcare professionals, so that they would become qualified to offer these therapies. Current training depends on individual initiative. Therefore, it may be affected by a lack of knowledge of CAT, a lack of initial training, little interest in the subject and insufficient resources. It is important to stress to midwives the importance of CAT training, so that they can provide suitable care for women who want to use these therapies. Therefore, it is essential to increase the courses for midwives so that they can broaden their knowledge of CAT for birth and provide effective care for women. Health authorities must ensure safe interventions and good practices, incorporate CAT into courses for health care professionals and into the health system, and contribute to standardizing the effective and safe use of CAT.

\section{Additional file}

\section{Additional file 1: Questionnaire for midwives.}

\section{Abbreviations}

CAM: Complementary and alternative medicine; CAT: Complementary and alternative therapies. In this study, the concept of CAT includes all nonpharmacological techniques for pain relief during birth;

TENS: Transcutaneous electrical nerve stimulation.

\section{Competing interests}

None of the authors had competing interests. This study was funded by a grant (PREUI 12/06) from the Research Committee of the UB University School of Nursing.

\section{Authors' contributions}

EMS contributed substantially to the conception and design of the study, the collection of data, the compilation of results and the final report. This study is part of EMS'S doctoral thesis. AVS helped to validate the questionnaire and assisted in the statistical analysis of data. JGT supervised the design of the study, contacted some of the hospitals to obtain authorization to gather data, sought funding for the study and made considerable intellectual contributions to the revision of the manuscript. All the authors read and approved the final version of the manuscript.

\section{Acknowledgements}

We are grateful to all of the participating hospitals, directors of nursing, midwives and nursing supervisors.

\section{Author details}

${ }^{1}$ Department of Public Health, Mental Health and Perinatal Nursing, University School of Nursing, University of Barcelona, Barcelona, Spain ${ }^{2}$ Department of Public Health, Faculty of Medicine, University of Barcelona, Barcelona, Spain.

Received: 14 May 2013 Accepted: 30 October 2013

Published: 15 November 2013

\section{References}

1. Allison N: The illustrated encyclopedia of body-mind disciplines. New York: Rosen Pub Group; 1999.

2. Wieland L, Manheimer E, Berman B: Development and classification of an operational definition of complementary and alternative medicine for the Cochrane collaboration. Altern Ther Health Med 2011, 17(2):50-59.

3. Adams J, Sibbritt D, Broom A, Loxton D, Pirotta M, Humphreys J, et al: A comparison of complementary and alternative medicine users and use across geographical areas: A national survey of 1,427 women. BMC Complement Altern Med 2011, 7(11):85.

4. Gentz B: Alternative therapies for the management of pain in labor and delivery. Clin Obstet Gynecol 2001, 44(4):704-732.

5. Orden SAS/1349/2009: de 6 de mayo, por la que se aprueba y publica el programa formativo de la especialidad de Enfermería Obstétrico-Ginecológica (Matrona). http://www.boe.es/buscar/doc.php? id=BOE-A-2009-8881

6. Adams J, Lui C, Sibbritt D, Broom A, Wardle J, Homer C: Attitudes and referral practices of maternity care professionals with regard to complementary and alternative medicine: an integrative review. J Adv Nurs 2011, 67(3):472-483.

7. Adams J: An exploratory study of complementary and alternative medicine in hospital midwifery: Models of care and professional struggle. Complement Ther Clin Pract 2006, 12:40-47.

8. Ministerio de sanidad, política social e igualdad: Terápias naturales. http:// www.msssi.gob.es/novedades/docs/analisisSituacionTNatu.pdf. 
9. National Center for Complementary and Alternative Medicine (NCCAM): What is CAM?. http://nccam.nih.gov/health/whatiscam.

10. Duarte M: Medicina occidental y otras alternativas: ¿es posible su complementariedad? reflexiones conceptuales. Cad Saude Publica 2003, 19(2):635-643

11. López-Ruíz J, Arqué-Blanco M: Bases per a l'acreditació de la competència dels professionals infermers en teràpies naturals i complementàries. Barcelona: Col legi Oficial d'infermeria de Barcelona; 2009.

12. Sibbritt D, Adams J: Developing and promoting public health methods for integrative medicine: Examples from the field in Australia. Zhong $X_{i} Y_{i}$ Jie He Xue Bao 2011, 9(3):233-36.

13. Lázaro M: Terapias alternativas y complementarias: evidencia clínica. SEDENE. 2008, 27:12-26.

14. O'Regan P, Wills T: The growth of complementary therapies: and their benefits in the perioperative setting. J Perioper Pract 2009, 19(11):386-389.

15. Hirschkorna K, Bourgeaulta I: Actions speak louder than words: mainstream health providers' definitions and behaviour regarding complementary and alternative medicine. Complement Ther Clin Pract 2007, 13:29-37.

16. Gaylord S, Mann D: Rationales for CAM education in health professions training programs. Acad Med 2007, 82:927-933.

17. Connelly E, Elmer $\mathrm{P}$, Morris C, Zwickey $H$ : The vanguard faculty program: research training for complementary and alternative medicine faculty. J Altern Complement Med 2010, 16(10):1117-1123.

18. Ezzo J, Wright K, Hadhazy V, Bahr-Robertson M, Mc Beckner W, Covington $M$, et al: Use of the cochrane electronic library in complementary and alternative medicine courses in medical schools: is the giant lost in cyberspace? J Altern Complement Med 2002, 8(5):681-686.

19. Gaster B, Unterborn J, Scott R, Schneeweiss R: What should students learn about complementary and alternative medicine? Acad Med 2007, 82:934-938

20. Marcus D, McCullough L: An evaluation of the evidence in "Evidencebased" integrative medicine programs. Acad Med 2009, 84:1229-1234.

21. Armi $H$, Haramati $A$ : Basic science to develop an innovative program in complementary and alternative medicine. J Int Assoc Med Sci Educ 2010, 20(2):48-55.

22. Lee M, Ben R, Wimsatt L, Cornman J, Hedgecock J, Gerik S, et al: Integrating complementary and alternative medicine instruction into health professions education: Organizational and instructional strategies. Acad Med 2007, 82:939-945.

23. Pearson $\mathrm{N}$, Chesney M: The CAM education program of the national complementary and alternative medicine: An overview. Acad Med 2007, 82:921-926.

24. Rodríguez M, Rojas M, Abreu A, Rodríguez J: Enfermería y el presente de las terapias complementarias. Rev ROL Enferm 2002, 25(4):248-252.

25. Muñoz-Sellés E, Goberna-Tricas J: Oferta formativa en terapias alternativas y complementarias para la asistencia al parto. Matronas Prof 2012, 13(2):50-54.

26. International Confederation of Midwives: Essential competencies for basic midwifery practice. http://www.internationalmidwives.org/what-we-do/ education-coredocuments/essential-competencies-basic-midwifery-practice/.

27. Ernst $E$, Watson L: Midwives' use of complementary/alternative treatments. Midwifery 2012, 28(6):772-777.

28. Mureyi D, Monera T, Maponga C: Prevalence and patterns of prenatal use of traditional medicine among women at selected harare clinics: A cross-sectional study. BMC Complement Altern Med 2012, 12:164.

29. Smith C, Levett K, Collins C, Crowther C: Relaxation techniques for pain management in labor. Cochrane Database Syst Rev 2011, CD009514(12). 10.1002/14651858.CD009514.

30. Smith C, Collins C, Crowther C, Levett K: Acupuntura o acupresión para el tratamiento del dolor durante el trabajo de parto. Cochrane Database Syst Rev 2011, CD009232(7). 10.1002/14651858.CD009232.

31. Smith C, Collins C, Cyna A, Crowther C: Tratamientos complementarios y alternativos para el manejo del dolor durante el trabajo de parto (revisión cochrane traducida). In La Biblioteca Cochrane Plus. 4th edition. Oxford; 2008. Update Software Ltd. http://www.bibliotecacochrane.com/ BCPGetDocument.asp?SessionID=\%207819852\&DocumentID=CD003521

32. Slade S: Labor: Non Pharmacological Pain Relief. In Joanna Brigs Institute. Evidence Summarie. COnNECT+. http://connect.jbiconnectplus.org/Search. aspx.

33. Cluet E, Nikodem V, McCandilish R, Burns E: Inmersión en agua para el embarazo, trabajo de parto y parto; (revisión cochrane traducida). 2nd edition. Oxford: La biblioteca Cochrane plus; 2008. Update Software Ltd. [http://www.bibliotecacochrane.com/BCPGetDocument.asp?SessionID=\% 207819852\&DocumentID=CD000111 (translated from The Cochrane Library, 2008 Issue 2. Chichester, UK: John Wiley \& Sons, Ltd]

34. Goberna-Tricas J: Dones i procreació: Ėtica de les pràctiques sanitàries i la relació assistencial en l'embaràs i naixement. (PhD thesis). Barcelona: Universitat de Barcelona; 2009. http://hdl.handle.net/10803/1762.

35. Hodnett E, Gates S, Hofmeyr G, Sakala C: Apoyo continuo para las mujeres durante el parto (revisión cochrane traducida). In La Biblioteca Cochrane Plus. 4th edition. Oxford; 2008. Update Software Ltd [http://www. bibliotecacochrane.com/BCPGetDocument.asp?SessionID=\% 207819852\&Document|D=CD003766. (Translated from The Cochrane Library, 2008 Issue 3. Chichester, UK: John Wiley \& Sons, Ltd]

36. East C, Begg L, Henshall N, Marchant P, Wallace K: Frío local para el alivio del dolor producido por el trauma perineal prolongado durante el parto (revisión cochrane traducida). In La Biblioteca Cochrane Plus. 4th edition. Oxford; 2008. Update Software http://www.bibliotecacochrane.com/ BCPGetDocument.asp?SessionID=\%207819852\&DocumentID=CD006304

37. Dowswell T, Bedwell C, Lavender T, Neilson J: Estimulación nerviosa eléctrica transcutánea (ENET) para el alivio del dolor durante el trabajo de parto (revision cochrane traducida). In La Biblioteca Cochrane Plus. 3rd edition. Oxford; 2009. Update Software Ltd http://www.bibliotecacochrane.com/ BCPGetDocument.asp?SessionID=\%207819852\&DocumentID=CD007214

38. Derry S, Straube S, Moore R, Hancock H, Collins S: Intracutaneous or subcutaneous sterile water injection compared with blinded controls for pain management in labor. Cochrane Database Syst Rev 2012, 18(1):CD009107. doi: 10 1002/14651858 CD009107 pub2.

39. Departament de Salut: Protocol per a l'assistència natural al part normal. Barcelona: Direcció General de Salut Pública. Generalitat de Catalunya; 2007.

40. Observatorio de Salud de la Mujer y del Sistema Nacional de Salud. Dirección General. Agencia de Calidad del Sistema Nacional de Salud: Estrategia de atención al parto normal en el Sistema Nacional de Salud. Madrid: Ministerio de sanidad y consumo; 2008.

41. Ministerio de sanidad, política social e igualdad: Estrategia Nacional de Salud Sexual y Reproductiva. Madrid: Ministerio de Sanidad, política social e igualdad; 2011.

42. FAME: Iniciativa parto normal. Documento de consenso. Barcelona: Federación de Asociaciones de Matronas de España; 2007.

43. Ministerio de Sanidad, política social: Guía de Práctica Clínica sobre la Atención al Parto Normal. Vitoria-Gasteiz: Eusko Jaurlaritzaren Argitalpen Zerbitzu Nagusia. Servicio Central de Publicaciones del Gobierno Vasco; 2010.

44. Agencia de Calidad del Sistema Nacional de Salud. Observatorio de salud de las mujeres: Plan de Parto y Nacimiento. Estrategia de atención al parto normal. Madrid: Ministerio de Sanidad, Política Social e Igualdad; 2010.

45. Bailey J, Crane P, Nugent C: Childbirth education and birth plans. Obstet Gynecol Clin North Am 2008, 35(3):497-509.

46. Lothian J: Birth plans: The good, the bad, and the future. JOGNN 2006 35(2):295-303

47. Dayhew M, Wilkinson J, Simpson M: Complementary and alternative medicine and the search for knowledge by conventional health care practitioners. Contemp Nurse 2009, 33(1):41-49.

48. Departament de Salut: El sistema de salut i la xarxa sanitària pública de catalunya. línies estratègiques i evolució 2004-2009. Barcelona: Generalitat de Catalunya; 2009

49. Hastings-Tolsma M, Terada M: Complementary medicine use by midwives in the U.S. Complement Ther Clin Pract 2009, 15:212-19.

50. Quandt SA, Verhoef MJ, Arcury TA, Lewith GT, Steinsbekk A, Kristoffersen AE, et al: Development of an international questionnaire to measure use of complementary and alternative medicine (I-CAM-Q). J Altern Complement Med 2009, 15(4):331-9.

51. Fincham J: Response rates and responsiveness for surveys, standards, and the journal. Am J Pharm Educ 2008, 15(2):43. 72

52. Bjersa $K$, Victorin E, Olsén M: Knowledge about complementary, alternative adn integrative medicine (CAM) among registered health care providers in swedish surgical care: A national survey among university hospitals. BMC Complement Altern Med 2012, 12:42.

53. Forcades T: Estudi observacional de l'impacte de les medicines alternatives en els estudiants de medicina de catalunya. (PhD thesis). Barcelona: Universitat de Barcelona; 2004

54. Shorofi S, Arbo P: Nurses' knowledge, attitudes, and professional use of complementary and alternative medicine (CAM): A survey at five 
metropolitan hospitals in adelaide. Complement Ther Clin Pract 2010, 16:229-234.

55. Fernandez A, Salvador T: Formación y aplicación de las terapias complementarias en los cuidados de enfermería al paciente oncológico. Nursing 2010, 28(7):52-58.

56. Wiebelitz K, Goecke T, Brach J, Beer A: Use of complementary and alternative medicine in obstetrics. Br J Midwifery 2009, 17(3):169-175.

57. Stone J: Using complementary therapies within nursing: Some ethical and legal considerations. Complement Therap Nurs Midwifery 1999, 5:46-50.

58. Fournier C: Formar a los empleados de mayor edad: Un objetivo a reformular. Calificaciones\&empleo 2011, 78:1-4.

59. Samuels N, Zisk-Rony R, Singerm SR, et al: Use of and attitudes toward complementary and alternative medicine among nurse-midwives in Israel. Am J Obstet Gynecol 2010, 203:341-347.

doi:10.1186/1472-6882-13-318

Cite this article as: Muñoz-Sellés et al:: Use of alternative and

complementary therapies in labor and delivery care: a cross-sectional study of midwives' training in Catalan hospitals

accredited as centers for normal birth. BMC Complementary and Alternative Medicine 2013 13:318.

\section{Submit your next manuscript to BioMed Central and take full advantage of:}

- Convenient online submission

- Thorough peer review

- No space constraints or color figure charges

- Immediate publication on acceptance

- Inclusion in PubMed, CAS, Scopus and Google Scholar

- Research which is freely available for redistribution 